Revista de Indias, 1999, vol. LIX, núm. 217

\title{
LA CIUDADANIZACIÓN DEL «INDIO BÁRBARO». POLÍTICAS OFICIALES Y OFICIOSAS HACIA LA POBLACIÓN INDÍGENA DE LA PAMPA Y LA PATAGONIA, 1870-1920
}

\author{
POR \\ MÓNICA QUIJADA \\ Centro de Estudios Históricos, CSIC*
}

En este trabajo se aborda el problema del tratamiento del tema indígena en la Argentina, en el último cuarto del siglo XIX y principios del XX, a partir de la ocupación militar de los extensos territorios hasta entonces habitados por indígenas no sometidos. En él se analiza la complejidad de las visiones sobre el indígena y su estadio de civilización, y se demuestra la existencia de una política de concesión de tierras y la puesta en marcha de una serie de iniciativas destinadas a la integración de un colectivo que, lejos de haber desaparecido como saldo de la campaña militar, fue el objeto de preocupaciones oficiales y oficiosas destinadas a definir el lugar que los aborígenes vencidos debian ocupar en la nacionalidad que se estaba construyendo. Se argumentan asimismo las condiciones de la conversión de los indios en ciudadanos en el marco del concepto estrictamente territorial de nación que fue característico de la construcción nacional argentina.

Al promediar el siglo XIX, entre el norte de México y la Tierra del Fuego se extendían miles de kilómetros cuadrados (cerca de la mitad de la geografía hispanoamericana) a los que no alcanzaba el control de los estados centrales, y que estaban habitados por indígenas no sometidos. Parte de esos territorios se situaba en el extremo sur de América: la zona del Chaco, las pampas y la Patagonia, que no fueron ocupados por las autoridades republicanas hasta los últimos años del

* Quiero agradecer muy especialmente a Juan Carlos Mauriño, Susana F. de Mauriño y Marta M. de Franco la colaboración inestimable que me prestaron para realizar en archivos y bibliotecas de Buenos Aires la investigación que fundamenta este trabajo. Un segundo reconocimiento es para Paloma Largacha, a cuyo esfuerzo y eficiencia debo la transcripción de un número importante de cintas grabadas con información de archivo.Este artículo se inscribe en los proyectos de investigación de la DGES PB97-1125 «El papel de las élites intelectuales en la formación de modelos colectivos: la historiografía natural y política en el mundo hispano, siglos XVI-XIX», y PB96-0868 «Raza, nación y pensamiento científico en la construcción de las identidades americanas en el tránsito de siglo, 1870-1930».

R. I., $1999, \mathrm{n}^{\circ} 217$ 
siglo XIX e incluso ya entrado el XX. Tal expansión se produjo a partir de un episodio conocido como la Campaña del Desierto, que implicó el avance militar de la población criolla sobre las tribus indígenas que mantenían su independencia.

Hasta fechas muy recientes, los trabajos que se ocupaban de la Campaña del Desierto tendían a ver los enfrentamientos entre blancos e indios como resultado del choque de dos estadios disímiles e irreconciliables de civilización. Desde esta perspectiva se consideraba que «las discrepancias eran enormes. Siglos de civilización y vida conjunta de pueblos y razas, se enfrentaban a gente sin pasado, sin leyes, y sin contacto con otros». En esta visión monocolor los indígenas eran «salvajes crueles, sucios y lascivos, de instintos perversos, taimados, hipócritas e imposibles de amoldarse a un orden o cultura determinada, inhábiles para el trabajo reglado y siempre dispuestos a degenerarse en el alcoholismo» ${ }^{2}$. De hecho, la interacción de la sociedad mayoritaria argentina con los indígenas de la pampa y la Patagonia ha dado lugar a un conjunto de mitologías y percepciones que han conformado un imaginario tan constante como pertinaz. En primer lugar está el mito de ese indígena bárbaro, nómade, de costumbres primitivas y salvajes y economía elemental. En relación con esa imagen existe la idea de que la población aborigen, hasta su rendición final, careció de vínculos con la sociedad blanca que no estuvieran basados en la violencia y la rapiña. Otra percepción generalizada es la que afirma que la Conquista del Desierto se saldó con el exterminio de los nativos, conllevando su práctica desaparición física. Una cuarta convicción, que se desprende de esta última imagen, se refiere a que los gobiernos sucesivos no habrían contado a la situación indígena entre sus preocupaciones oficiales.

En los últimos años, investigaciones como las de R. Mandrini, M.A. Palermo y L. Nacuzzi ${ }^{3}$ han demostrado que la organización socioeconómica de los indígenas pampeanos era más compleja de lo que reconociera la historiografía tradicional, y han puesto también de manifiesto la existencia de interacciones permanentes, en diversos grados, de los aborígenes con la sociedad mayoritaria.

Dentro de ese marco interpretativo, este trabajo intenta abundar en la complejidad de las visiones sobre el indígena en el último cuarto del siglo XIX y primeros de éste, así como demostrar la existencia de una política de concesión de tierras y la puesta en marcha de una serie de iniciativas destinadas a la inte-

2 Guillermo V. STUCKert, La campaña del General Roca al desierto y la Academia Nacional de Ciencias, Córdoba, Academia Nacional de Ciencias, Miscelánea No. 40, 1961, pp. 5 y 13.

3 Cfr. entre otros Raúl MANDRINI, «Desarrollo de una sociedad indígena pastoril en el área interserrana bonaerense», Anuario del IEHS, vol. II, 1987; ídem, «Indios y fronteras en el área pampeana (siglos XVI-XIX). Balance y perspectivas», Anuario del IEHS, vol. VII, 1992; Raúl MANDRINI y Andrea REGUERA, Huellas en la tierra. Indios, agricultores y hacendados en la pampa bonaerense, Tandil, IEHS, 1993; Lidia R. NACUZZI, «'Nómades' versus 'sedentarios' en Patagonia (siglos XVIII-XIX», Cuadernos del Instituto Nacional de Antropología y Pensamiento Latinoamericano, vol. 14, 1992-93, pp.81-92; Miguel Angel PALERMO, «Reflexiones sobre el llamado 'complejo ecuestre' en la Argentina», Runa, vol. XVI, 1986; ídem, «La innovación agropecuaria entre los indígenas pampeano-patagónicos. Génesis y procesos», Anuario del IEHS, vol. VIII, 1988, pp. 43-90.

R. I., 1999, n. 217 
gración de un colectivo que, lejos de haber desaparecido como saldo de la campaña militar, fue el objeto de preocupaciones oficiales y oficiosas destinadas a definir el lugar que los aborígenes vencidos debían ocupar en la nacionalidad que se estaba construyendo. En las páginas que siguen me referiré en primer lugar a la sociedad indígena de la pampa y la Patagonia y a sus interacciones con la sociedad mayoritaria; luego me ocuparé de las visiones sobre el indio y los debates sobre las posibles políticas a seguir una vez dominados por las armas, y finalmente me extenderé sobre la política de tierras y las iniciativas para lograr la integración de los indígenas a la ciudadanía.

\section{LA FRONTERA: UN ESPACIO DE CONTACTO E INTERACCIÓN}

A mediados del siglo XIX, los territorios habitados por indígenas no sometidos representaban aproximadamente el cincuenta por ciento del espacio geográfico argentino. Entre esas tierras y las ocupadas por la sociedad mayoritaria se extendía lo que en la época era conocido como «fronteras interiores», la más importante de las cuales era una línea imaginaria horizontal que -de este a oesteiba aproximadamente desde el sur de la provincia de Mendoza hasta el océano Atlántico, y que aislaba la Patagonia y parte de las pampas de los territorios del norte. Al sur de esa línea se extendía el «desierto», eufemismo que simbolizaba la ausencia o escasez de asentamientos «blancos» y el rechazo de la sociedad mayoritaria a conceder a los grupos indígenas que lo habitaban el carácter y estatus de «poblaciones». Una segunda «frontera interior», situada al noreste, circundaba la zona del Chaco, reducto de grupos indígenas que consiguieron mantener su autonomía hasta comienzos del siglo XX.

En ambos casos, y muy en particular en el de los lindes meridionales, la utilización del término «frontera» asumía una fuerza simbólica particular y ciertamente equívoca. En efecto, en el imaginario de la sociedad mayoritaria la «frontera» se concebía como una línea divisoria casi física. Sin embargo, desde hace varios años la investigación viene demostrando que esa frontera, más que un límite o separación, actuaba como «un área de interrelación entre dos sociedades distintas, en la que se operaban procesos económicos, sociales, políticos y culturales específicos» ${ }^{4}$. Un mundo de criollos, indígenas y mestizos cruzado por múltiples líneas de interacción, aculturación e influencias recíprocas.

La situación de contacto constante entre las etnias locales y la sociedad colonial primero y republicana después, unida al mantenimiento por parte de las primeras de su autonomía y el control de su espacio a lo largo de más de tres siglos, hizo que la incorporación de elementos hispánicos por parte de éstas no fuera

\footnotetext{
${ }^{4}$ MANDRINI, «Indios y fronteras...» [3] p. 63.
} 
inducida ni forzada, sino consecuencia de un proceso de selección propio ${ }^{5}$. En la zona pampeana y patagónica este fenómeno gradual de aculturación condujo a la progresiva aparición de formas económicas complejas que incluían principalmente el pastoreo de inmensos rebaños de ganado (sobre todo vacuno y en mucha menor medida ovino) así como la agricultura y la producción artesanal, además de la caza y la recolección. Un complejo sistema de intercambio de animales, manufacturas y materias primas vinculaba a los distintos grupos indígenas entre sí y con la sociedad criolla ${ }^{6}$. El eje principal de las relaciones entre ambas sociedades fue, precisamente, el comercio, integrado en los mercados regionales $\mathrm{y}$, por parte indígena, aprovechando las contradicciones de intereses entre distintos sectores de la Colonia y posteriormente de la República ${ }^{7}$. Desde esta perspectiva, el comercio con los indígenas fue un resultado de la interacción de las dos sociedades en las áreas de frontera. Pero también, a partir de la segunda mitad del siglo XVIII, fue utilizado por los Borbones como una política alternativa a la conquista física o espiritual ${ }^{8}$, estrategia que sería heredada por los republicanos. Los indios entregaban plumas de ñandú, pieles y sus propias manufacturas en cuero y tejidos a cambio de bebidas, armas, herramientas, monturas, espuelas, yerba mate, azúcar y tabaco. Este tipo de intercambios fue un factor de aculturación de primer orden, por el cual los aborígenes adoptaron bienes y, a través de ellos, usos de la sociedad mayoritaria, en tanto que en el seno de esta última se asumían préstamos tales como el tradicional poncho tejido en telares indígenas.

Pero no fue el comercio el único ámbito de comunicación entre las dos sociedades. Desde el siglo XVIII fue constante la cooperación indígena en el servicio de las armas. Durante la época borbónica, la corona procuró el apoyo de los indios para la protección territorial frente a las pretensiones de otros estados imperiales, buscando convertir a aquéllos en «soldados de frontera» ${ }^{9}$. Este sistema sería heredado por el período republicano en la figura de los «indios amigos», que a cambio de una serie de concesiones y regalos asumían el compromiso de proteger la frontera de los ataques de indígenas hostiles ${ }^{10}$. Grupos de nativos intervendrían también en los conflictos internos de la sociedad blanca. Durante

5 PALERMO, «La innovación agropecuaria...» [3].

${ }^{6}$ MANDRINi [3], NACUZZi [3], PALeRmo [3]. Lidia R. NACUZZI: «La cuestión del nomadismo entre los Tehuelches», Memoria americana - Cuadernos de Etnohistoria, No. 1, 1991, pp. 103-133.

7 PALERMO, «La innovación agropecuaria...» [3] p.45; MANDRINI, «Desarrollo de una sociedad indígena...» [3] passim.

8 David J. WEBER: «Borbones y Bárbaros. Centro y periferia en la reformulación de la política de España hacia los indígenas no sometidos», Anuario del IEHS, vol. 13, 1998, pp. 147-171.

9 Idem, p.158 y Carlos LAZARO AVILA, «El reformismo borbónico y los indígenas fronterizos americanos», en Agustín GuIMERÁ (ed.): El reformismo borbónico, Madrid, Alianza Editorial, 1996, pp.

${ }^{10} \mathrm{La}$ función de los «indios amigos» era comparada en la época con la que cumplían los spahis en la Argelia francesa y los cipayos en la India ocupada por los ingleses. Cfr. por ejemplo $\mathrm{La}$ Nación, Buenos Aires, 8 de enero de 1876.

R. I., 1999, n. ${ }^{\circ} 217$ 
las invasiones inglesas de 1806-7 hubo ofrecimientos de caciques de poner sus lanzas al servicio del Cabildo de Buenos Aires, y más tarde los indígenas intervendrían activamente en las guerras de la independencia, dividiendo sus apoyos entre los bandos enfrentados. Este tipo de participación se prolongaría durante los largos años de anarquía, guerras civiles y enfrentamientos internos de todo tipo que sobrevinieron con posterioridad a la independencia. Los diversos grupos indígenas no dudaron en alquilar sus lanzas a uno u otro contendiente y la facción federal (enfrentada a los centralistas) buscó a lo largo de los años establecer alianzas con los nativos. De hecho, estos últimos supieron sacar partido de las luchas intestinas en el seno de la sociedad mayoritaria, y nada temían tanto como el final de las contiendas civiles que imaginaban implicaría -como de hecho sucedió- la unión de las fuerzas que antaño estuvieron enfrentadas, mancomunándose para acabar con la autonomía indígena.

A la inversa, era común que los comandantes de frontera interviniesen en las disputas entre tribus y caciques; muchos miembros de la sociedad blanca, ya fueran delincuentes huidos de la justicia, cautivos o comerciantes, vivían en las tolderías (asentamientos indígenas) de forma transitoria o permanente. $\mathrm{Y}$ algunas tribus indígenas se establecieron en territorio cristiano o huinca, en calidad de aliados o amigos; hubo caciques que llegaron a integrarse hasta el punto de ser considerados estancieros ${ }^{11}$. Los trasvasamientos culturales y las acciones recíprocas fueron por ende múltiples y afectaron particularmente a las tribus indias, pero también a las poblaciones «cristianas» de frontera.

En este marco de interacción continua, se sucedían períodos de paz y de violencia. En estos últimos -que se fueron incrementando en extensión y virulencia desde el siglo XVIII- las razzias indígenas contra las estancias criollas (los muy temidos malones) combinaban la captura de cautivos con robos de grandes cantidades de cabezas de ganado. Un factor agravante era el hecho de que los circuitos comerciales indígenas implicaban la conducción transcordillerana del ganado robado, que era vendido en los mercados fronterizos chilenos; lo que entrañaba añadir conflictos políticos y de soberanía nacional a las cuantiosas pérdidas económicas de las estancias argentinas. De hecho, es difícil comprender las interacciones entre las dos sociedades si no se tienen en cuenta diversos factores originados en el vecino país de Chile.

El más significativo de esos factores es el fenómeno conocido como la «araucanización» de las pampas, que se produjo a partir del siglo XVII; es decir, el proceso de sustitución gradual de las antiguas culturas pampeanas por la araucana o mapuche, original del territorio chileno. Los movimientos de población de la margen occidental a la oriental de la cordillera implicaron una amplísima difusión de elementos culturales araucanos en las pampas argentinas, muy en parti-

11 MANDRINI, «Indios y fronteras...» [3] p.61; Carlos MARTINEZ SARASOLA, Nuestros paisanos los indios, Buenos Aires, Editorial Emecé, 1972, cap. IV. 
cular la lengua ${ }^{12}$. Según recientes investigaciones ${ }^{13}$ este fenómeno se enmarca en un complejo proceso de cambios internos que estaba experimentando la sociedad indígena pampeana, favorecido por los contactos con la sociedad colonial ${ }^{14}$. Desde el siglo XVII hasta principios del XIX la incorporación de rasgos culturales araucanos aparece ligada, fundamentalmente, al proceso de diferenciación interna de las sociedades pampeanas, a través de mecanismos como la intensificación de las relaciones de intercambio entre los grupos indígenas y el establecimiento de redes de parentesco interétnicas mediante la presencia de linajes chilenos al este de los Andes, que contribuyó a conformar una extensa trama de vínculos que unían a etnias asentadas a ambos lados de la cordillera ${ }^{15}$. En ese contexto se habría producido la incorporación de una serie de bienes de prestigio de origen araucano por parte de las etnias locales, al tiempo que las poblaciones trasvasadas desde Chile al territorio argentino habrían adoptado elementos de las formas de vida de los cazadores pampeanos. Cuando en la primera mitad del siglo XIX se produjo una gran migración de grupos araucanos a la zona pampeana, que profundizó y generalizó el proceso de influencia, esta última etapa de la penetración mapuche operó sobre una región que ya estaba muy araucanizada, con un alto grado de homogenización cultural y lingüística.

Estos movimientos de población desde la margen occidental a la oriental de la cordillera estuvieron motivados por el interés de los grupos chilenos en la riqueza ganadera de las pampas argentinas, primero el ganado cimarrón y, al ir desapareciendo éste -hacia mediados del siglo XVIII ${ }^{16}$ - los inmensos rebaños vacunos de las estancias argentinas, cuya cría se iba convirtiendo gradualmente en la base de la economía regional. Esto dio lugar a una competencia cada vez más acentuada entre ambas sociedades por el control de tierras y animales, y es lo que subyace al incremento de la violencia en las relaciones entre ambas a lo largo del siglo XIX.

12 Salvador CANAlS FraU, «Expansion of the Araucanians in Argentine», en Handbook of South American Indians, Washington, Smithsonian Institution-Bureau of American Ethnology, 1946, Bulletin Nr 143, vol. II, pp.761-766.

${ }_{13}$ Cfr. Sara ORTELLI: «La 'araucanización' de las pampas: ¿Realidad histórica o construcción de los etnólogos?», Anuario del IEHS, 1996, pp. 208-225. En este trabajo se hacen importantes matizaciones a las connotaciones excesivamente difusionistas del concepto de «araucanización», vinculado por la historiografía tradicional exclusivamente a los fenómenos migratorios.

14 Sobre las transformaciones inducidas por el contacto con los españoles en el seno de agrupaciones indígenas que mantenían su autonomía, véase Raúl J. MANDRINI: «Las transformaciones de la economía indígena bonaerense (ca. 1600-1820)», en Raúl MANDRINI y Andrea REGUERA (comps.): Huellas en la tierra... [3] pp. 45-74.

15 Idem, p. 207.

16 En la desaparición del ganado cimarrón tuvieron que ver tanto las matanzas incontroladas para obtener cueros realizadas por la población de origen europeo, como los grandes arreos transandinos de animales llevados a cabo por los indígenas.

R. I., $1999, \mathrm{n}^{\circ} 217$ 
Para comprender este proceso es importante tener en cuenta el significado que las pampas argentinas asumían desde la perspectiva de los mapuches en el lado chileno de la cordillera. Constituían éstos una sociedad agrícola, ganadera y militar, en la que las virtudes ligadas a la guerra eran las más apreciadas ${ }^{17}$. Los relatos recogidos desde finales del siglo XIX, que conservan hasta el día de hoy la memoria de las relaciones transcordilleranas, muestran que para las etnias araucanas las pampas constituían un sitio de atracción y fascinación; eran «el lugar de fácil enriquecimiento, de grandes proezas militares donde los hombres se cubrían de honores y glorias... durante el siglo XVIII y XIX el viaje a la pampa se transformó en una especie de ritual de iniciación de los jóvenes guerreros» ${ }^{18}$. Ganados, cautivas y gloria se obtenían mediante las acciones llamadas malones o malocas.

Las malocas $^{19}$ eran ataques sorpresivos realizados a las estancias y poblaciones, durante los cuales los guerreros se dedicaban al saqueo, al robo y a la destrucción. La apropiación de mujeres, niños y, sobre todo, ganados y caballos eran el objetivo de la acción. Los animales eran la base de la economía indígena y principal elemento de cambio; los niños, futuros guerreros; y las mujeres «españolas» conferían prestigio, proporcionaban sangre nueva que «fortalecía la raza», y daban a los caciques hijos bilingües útiles en el trato con la sociedad mayoritaria $^{20}$. Como ha dicho Leandro León Solís, «en más de un sentido, las malocas eran una forma de guerra chica, sin los rasgos épicos de la Gran Guerra de Arauco, pero mucho más feroz y brutal. El lonco (jefe) maloquero retornaba a Chile con suficientes riquezas y prestigio» que le permitían asumir posiciones de autoridad entre los suyos ${ }^{21}$. El maloqueo era una estrategia y un medio; los mismos individuos que en Chile entablaban alianzas con las tropas coloniales o republicanas y actuaban como promotores de la paz, eran al mismo tiempo los principales responsables de la violencia maloquera en las estancias trasandinas de Mendoza, San Luis, Córdoba o Buenos Aires ${ }^{22}$.

Los malones o malocas podían adquirir dimensiones considerables. En un ataque realizado en 1780 al pago de Luján (provincia de Buenos Aires) participaron nada menos que 1.500 indios de lanza. Casi un siglo más tarde, en 1868, una invasión producida al sur de la actual provincia de Córdoba contó con 2.000 gue-

17 José BEngOA, Historia del pueblo mapuche, Santiago de Chile, Ediciones Sur, 1985, pp. 102-103.

18 Idem, p. 102.

19 Sobre la historia de las malocas, véase Leandro León Solís, Maloqueros y conchavadores en Araucanía y las Pampas, 1700-1800, Temuco, Ediciones Universidad de La Frontera, 1991.

20 BENGOA [17] pp. 109-111.

${ }^{21}$ Solís [19] pp.21-22. Afirma este autor que, en la medida que los maloqueros provenían de sus lejanos hábitats en la margen occidental de la cordillera y sólo permanecían temporalmente en los asentamientos orientales, «sus acciones contra los habitantes de las estancias y villorrios eran más brutales, audaces y sangrientas» (p. 37).

22 Idem, p. 17. 
rreros. Por otra parte, desde el último cuarto del siglo XVIII estas acciones dejaron de ser aisladas y esporádicas, para convertirse en empresas cuidadosamente planeadas ${ }^{23}$ en las que a veces participaban distintas etnias aliadas al efecto. En 1738, por ejemplo, y como respuesta a una operación de castigo llevada a cabo por las tropas coloniales, se formó en la pampa una confederación maloquera integrada por araucanos, tehuelches, huilliches, pehuenches y pampas ${ }^{24}$. Se trata de un antecedente directo de la gran confederación indígena creada al promediar el siglo XIX por el gran cacique mapuche Calfucurá.

Desde la perspectiva de la sociedad argentina, la llegada a su territorio de este conocido jefe mapuche -la que tuvo lugar en la primera mitad de la década de 1830- constituye un hito fundamental en la historia de las relaciones entre la sociedad mayoritaria y las etnias indígenas pampeanas. Aparentemente, y según testimonio del propio jefe indígena, Calfucurá fue llamado por el entonces Gobernador de Buenos Aires, Juan Manuel de Rosas 25 , con un objetivo que la documentación no aclara pero que coincide con el momento en que Rosas se aprestaba a realizar una campaña militar en las pampas. Se ha interpretado esta acción del Gobernador como el convencimiento por su parte de que Calfucurá era «el hombre indicado para gobernar la pampa». Lo cierto es que lo primero que hizo el caudillo mapuche fue enfrentarse y vencer a los indios voroganos liderados por el cacique Alón -bautizado Mariano Rondeau- lo cual parecería apoyar la citada interpretación. Pero si se tiene en cuenta que en la guerra de fronteras los llamados «indios amigos» constituían un elemento crucial para defender los fortines de los avances de las tribus belicosas, y que Rondeau y sus indios eran importantes aliados de las tropas republicanas, no parece tan clara la intencionalidad del astuto gobernador de Buenos Aires. Más probable es que Rosas buscase apli-

\footnotetext{
${ }^{23}$ Según Leandro León Solís, en la época de las guerras del Arauco (siglos XVI-XVII) el movimiento de guerreros a través de los pasos andinos estuvo destinado a reforzar las luchas indígenas contra la expansión española al sur del río Bío Bío, al tiempo que contribuía a abrir un segundo frente militar en la región transcordillerana de Cuyo (que perteneció a la Capitanía General de Chile hasta incorporarse al muy tardío Virreinato del Río de la Plata, creado en 1776). Gradualmente, el flujo a través de la cordillera fue perdiendo su carácter puramente militar para convertirse en un tráfico de bienes y animales basado sobre todo en el stock de ganado cimarrón. La rápida disminución de este último y el surgimiento de las estancias ganaderas en la periferia de las localidades hispano-criollas estimularon a los cazadores a convertirse en depredadores de las haciendas, produciéndose la transición definitiva del pastor-agricultor al cazador y luego al maloquero, motivado este último por el afán de saqueo, del cautiverio de mujeres y sobre todo el robo de miles de cabezas de ganado. Esta tendencia se consolidó a partir de la segunda mitad del siglo XVIII, convirtiendo al guerrero indígena en un formidable rival económico del hacendado hispano-criollo. SoLís [19] pp.61-63.

${ }^{24}$ Idem, pp.35-52.

25 En una carta de 1861 enviada por el propio Calfucurá, éste afirma: «También le diré que yo no estoy en estas tierras por mi gusto, ni tampoco soy de aquí, sino que fui llamado por Don Juan Manuel, porque estaba en Chile y soy chileno; y ahora hace como treinta años que estoy en estas tierras». Citado en BENGOA [17] p.97.
}

R. I., 1999, n. ${ }^{\circ} 217$ 
car el viejo sistema español de favorecer los enfrentamientos entre las etnias, siguiendo el adagio de «divide y vencerás». Pero era muy difícil prever el notable grado de astucia y capacidad de convocatoria de que haría alarde el gran cacique mapuche.

Con anterioridad al trasvase de los grupos liderados por Calfucurá, el flujo regular de los maloqueros ya había generado asentamientos permanentes de linajes araucanos en la pampa y la Patagonia, en una forma de infiltración pacífica que permitía asegurar el control de puntos estratégicos. En particular, desde finales del siglo XVIII y sobre todo a partir de la Independencia se produjo un incremento de la expansión mapuche ${ }^{26}$ principalmente en la región del Neuquén, el llamado «País de las Manzanas», extendiéndose desde allí a las áreas centrales pampeanas. Pero ninguna de esas migraciones estables tuvo, para la sociedad argentina, el significado y el alcance de las acciones encabezadas por el mencionado cacique, aunque las tribus «manzaneras» fueron en gran parte las que dieron fuerza y prestigio a la confederación fundada por Calfucurá ${ }^{27}$.

El viejo cacique consiguió unir a las tribus mapuches, tehuelches, manzaneras, voroganas y huilliches y mantuvo en jaque a la sociedad mayoritaria a lo largo de varias décadas. En ese período alternó acciones pacíficas, entablando alianzas con los gobiernos argentinos, con épocas de maloqueo que llenaban de horror y pánico a las poblaciones. Los contactos y negociaciones con las autoridades criollas fueron llevados por Calfucurá como auténticas relaciones exteriores, siguiendo los usos de la sociedad mayoritaria. El caudillo mapuche llegó a tener una embajada estable en Buenos Aires, y su correspondencia ostentaba un sello diplomático con lanzas y boleadoras cruzadas ${ }^{28}$.

La República intentó controlar la violencia maloquera mediante la asignación a los indígenas de anualidades en forma de ganado, prendas de vestir, bebidas y víveres, que no siempre lograban impedir las invasiones a las estancias. Por otra parte, la lentitud en entregar las asignaciones o el olvido de su pago actuaban como nuevos acicates para la realización de malones. Otro factor del incremento de la violencia maloquera en la segunda mitad del siglo XIX fue la llegada a territorio argentino de nuevos grupos araucanos, empujados por las acciones militares chilenas, que entre 1869 y 1881 llevaron a cabo la última etapa de la conquista de la Araucanía.

En el territorio argentino y desde la perspectiva de la sociedad republicana, la violencia adoptó la forma de acciones militares que combinaban largos períodos

\footnotetext{
26 A estas migraciones no fue ajeno el hecho de que en Chile los indígenas apoyaron mayoritariamente a las tropas realistas durante la guerra de la Independencia.

27 Isabel HeRnANDEZ, Los indios de Argentina, Madrid, MAPFRE, Colección Pueblos y Lenguas Indígenas, 1992, pp.219-220.

${ }^{28}$ Kristine L. JONES, «Calfucurá and Namuncurá: Nation Builders of the Pampas», in Judith EwELL and William H. BEEZLEY (eds.), The Human Tradition in Latin America: the 19th Century, Wilmington, Delaware, 1989, pp.175-186.
} 
de estrategia defensiva -mediante la instalación de fortines a lo largo de la línea de frontera- con lapsos más breves pero contundentes de acción ofensiva. En el siglo XIX, los períodos más agudos de acometida militar fueron principalmente tres: 1821-22, 1833-34 (la campaña antes referida llevada a cabo por Rosas) y 1878-1885. Esta última fase de la confrontación bélica culminó con el sojuzgamiento de las tribus pampeanas y patagónicas. Coincidiendo con la victoria de las armas republicanas en los territorios meridionales, se iniciaron también acciones similares contra los indígenas de la región chaqueña que se extendieron hasta ya comenzado el siglo XX. Este largo período de ofensiva militar por parte de la sociedad mayoritaria recibió la ya mencionada denominación de «Conquista del Desierto». Con ella se puso punto final a la interacción de las «dos sociedades». $\mathrm{Al}$ cabo de la misma los grupos indígenas de la pampa y la Patagonia, y pocos años más tarde los del Chaco, perdieron su autonomía y el control del territorio que habitaban.

Desde la perspectiva de la sociedad mayoritaria, la culminación de este proceso tuvo dos implicaciones importantes para su definición como estado-nación moderno. Por un lado, la ocupación de esos vastos espacios supuso la eliminación de las últimas fronteras interiores y, con ello, la consolidación y unificación definitiva del territorio nacional, que quedaba así sujeto a una única autoridad y a un único sistema legal y productivo. La necesidad de unificar y homogenizar el territorio fue, junto con el temor a la violencia maloquera, uno de las principales motivaciones de la «Conquista del Desierto».

En lo que hace a la campaña en las pampas y la Patagonia, esta necesidad se vinculó también a la inseguridad que causaba la ausencia de una demarcación definitiva de la frontera con Chile. Aunque en la conquista de la Araucanía chilena y la campaña del Desierto argentina las tropas de ambos países unieron esfuerzos y logística para acabar con el enemigo común, las rivalidades fronterizas estuvieron muy presentes en las preocupaciones de los respectivos países. «No hay argentino que no comprenda en estos momentos, en que somos agredidos por las pretensiones chilenas, que debemos tomar posesión real y efectiva de la Patagonia», se afirmaba en la Cámara de Diputados en uno de los períodos de mayor ofensiva militar ${ }^{29}$. Desde la perspectiva argentina existía la convicción de que Chile «se ahogaba en su lengua de tierra», y que eso hacía tanto más peligrosa la percepción de una Patagonia «vacía» que alimentaba las ambiciones territoriales de ese país ${ }^{30}$. Por otra parte, se temía que las autoridades chilenas alegaran el principio de «utis posedetis» sobre las regiones meridionales al este de la cordillera, utilizando para ello el argumento de que estas últimas estaban pobladas por

${ }_{29}$ Mensaje del Poder Ejecutivo de la Provincia de Buenos Aires al Honorable Congreso de la Nación, Diario de Sesiones de la Cámara de Diputados, Año 1878, Tomo II, Buenos Aires, Imprenta y Librería de Mayo, 1879.

30 Cfr. El Nacional, Buenos Aires, 28 de octubre de 1878.

R. I., 1999, n. ${ }^{\circ} 217$ 
tribus araucanas, es decir, chilenas. Refiriéndose al hallazgo de que numerosos ciudadanos del país vecino convivían en las tolderías mapuches en territorio argentino, afirmaba por ejemplo un importante periódico de Buenos Aires: «Se conoce que las autoridades chilenas, con su vieja propaganda, han llevado al ánimo de esas gentes el convencimiento de que el territorio poblado por todas aquellas tribus pertenece a su país...» ${ }^{31}$. La percepción de la sociedad mapuche del lado oriental de la cordillera como más «civilizada» que las tribus pampeanas, unida al alto grado de mestizaje con la población chilena, incrementaba la preocupación argentina: «... los salvajes en aquellas tierras han dejado de serlo, mezclada como está su raza con los chilenos»; por ello, «estos bárbaros civilizados son una doble amenaza contra nuestros intereses» ${ }^{32}$. No es casual, por ende, que la ocupación de la Patagonia como resultado de la Conquista del Desierto coincidiera con una gran ofensiva técnica y diplomática para fijar definitivamente la frontera argentino-chilena.

Finalmente, este proceso que condujo a la culminación de la integración territorial argentina tuvo una segunda implicación: al finalizar la campaña, los indígenas que tradicionalmente habitaban la región -es decir, los que sobrevivieron a la acción militar- quedaron dentro de ese espacio nacional unificado. Como consecuencia de ello, a lo largo de los años que duró la guerra y con posterioridad a la misma la cuestión de «qué hacer con el indio» y, en concreto, la inclusión o no en la nacionalidad de esos grupos humanos que compartían el propio territorio, estuvo en el primer plano de los debates de la época.

\section{EL DEBATE}

El que un grupo compartiese el territorio del Estado no conducía necesariamente a una perspectiva de inclusión. Esto lo sabían las élites argentinas que tenían muy presentes, como lo demuestra con creces la documentación decimonónica, modelos contemporáneos de tratamiento de la cuestión indígena. De hecho, la Conquista del Desierto se llevó a cabo en la Argentina coetáneamente a las guerras indias de los Estados Unidos, se utilizaron los mismos y mortíferos rifles rémington, y se justificaron las ofensivas militares y la ocupación territorial a partir de premisas ideológicas semejantes. El hecho de mirarse en el espejo de la política indígena de los Estados Unidos puede interpretarse como una voluntad de emulación práctica; al fin y al cabo se trataba de un país americano con un problema semejante de violencia fronteriza y de poblaciones indígenas no sometidas. Sin embargo, las élites argentinas no dejaron de invocar otros modelos, como las referencias constantes a la misión de las armas francesas en Argelia y,

\footnotetext{
${ }^{31}$ El Nacional, Buenos Aires, 22 de febrero de 1879.

32 Ibidem.
} 
en mucho menor grado, a la ocupación inglesa de la India ${ }^{33}$. Esta utilización constante de ejemplos de la expansión decimonónica europea demuestra que, desde la perspectiva de la sociedad mayoritaria, el avance sobre los territorios ajenos al control del estado y el sometimiento de los «indios bárbaros» formaba parte de una misma gesta civilizatoria universal. Por ello, la justificación ideológica esgrimida por las élites argentinas superaba los límites de la estricta reivindicación nacional y quedó reflejada en los mismos conceptos de «conquista» y de «desierto», cuya utilización no fue ni casual, ni irrelevante.

Si la primera conquista, la realizada por la Corona de España, había incorporado los territorios del extremo sur de América al ámbito geopolítico de Occidente, esta segunda conquista venía a cerrar simbólicamente el círculo iniciado por aquella acción. Es decir, por su intermedio la porción más extrema del subcontinente debía quedar culturalmente integrada en el ámbito de la «civilización» occidental. Y el término «civilización» fue asumido con toda la carga culturalmente jerárquica que le imprimieron el pensamiento ilustrado y su hijo directo, el positivismo. Porque civilización era lo contrario de «desierto», concepto que, en el contexto de la ocupación de los territorios meridionales, implicaba que esa región era un no man's land, una «tierra de nadie», ya que sus pobladores tradicionales no contaban para la civilización, habían quedado evolutivamente marginados de ella.

En efecto: en la segunda mitad del siglo XIX la visión tradicional de ciertos grupos indígenas como «bárbaros» o «salvajes» se solapó con algunos conceptos clave acuñados y profusamente utilizados por el pensamiento occidental decimonónico en su relación con la diversidad humana: el de «primitivos»o «razas inferiores». Esta conceptualización, muy lejos de ser anecdótica o superficial, tenía importantes connotaciones, ya que se completaba con la noción de que los «pueblos primitivos» que entraban en contacto con un medio «más avanzado» estaban condenados a desaparecer. Dicho de otra manera: el avance de la «civilización» sobre las tierras más ignotas (como la Patagonia) se suponía «incontenible», a lo que se agregaba el convencimiento de que las formas fósiles de la vida primitiva sólo podían preservarse en el aislamiento, nunca en el contacto con «formas superiores», que llevaban todas las ventajas en el proceso de selección operado en la lucha por la existencia. Y no es ocioso recordar que el propio Darwin, en el

${ }^{33}$ Las referencias a estos hechos de la expansión decimonónica europea son constantes en los periódicos de la época. A modo de ejemplo, véase La Nación, Buenos Aires, 1 de enero de 1876 donde, con relación a un ataque masivo indígena aparecen frases tales como «Esto hace recordar la súbita sublevación de las tribus argelinas, en que las tropas francesas se despertaron un día al rumor de la insurrección en masa de todas las comarcas y el resplandor del incendio (...). En cuanto a las guarniciones de la frontera, sus atenciones, mayores que nunca y más que nunca difíciles y peligrosas, son las del ejército francés en presencia de la sublevación del Sáhara, en que el genio, el valor y la constancia militar deben hermanarse, aceptando y arrostrando la responsabilidad y la lucha con la austera virilidad de la religión del deber». 
contexto de su famoso viaje a América del Sur a bordo del Beagle (1831-1836), había afirmado que los indígenas que poblaban el extremo sur de América -así como las poblaciones autóctonas de Australia- no eran más que «fósiles vivientes», representantes de los más primitivos estadios de la evolución humana.

Es evidente que esta pespectiva traspasó las fronteras de los círculos científicos, porque al iniciarse el último cuarto del siglo, el pesimismo antropológico que condenaba a los indígenas a la extinción por ley fatal de la evolución se hallaba sólidamente afianzado en el imaginario de las élites rioplatenses, al igual que en todo el mundo occidental. Es frecuente encontrar en las fuentes de la época frases como la siguiente, tomada de la correspondencia del general Julio A. Roca, ideólogo y jefe supremo de la campaña del Desierto y Presidente de la República entre 1880 y 1886 :

«Es por efecto de una ley de la naturaleza que el indio sucumbe ante la invasión del hombre civilizado. En la lucha por la existencia en el mismo medio, la raza más débil ha de sucumbir ante la mejor dotada....»34.

Esta concepción determinista iba asociada a una perspectiva inversa y voluntarista: una nación civilizada no podía ni debía mantener en su seno formas fósiles de estadios inferiores de la evolución humana. Aunque no faltaran percepciones individuales sobre el alto grado de organización de las etnias mapuches, ello no modificaba de ninguna manera la conceptualización genérica de todas las tribus indígenas como «salvajes nómadas». Cierto es que, como se ha dicho, hoy se sabe que los indígenas de la pampa y la Patagonia tenían organizaciones socioeconómicas más complejas y hábitos más sedentarios de lo que tradicionalmente se ha reconocido. No obstante, a la hora de analizar la ideología y las políticas de la sociedad mayoritaria argentina con respecto a dicho segmento de la población, es importante tomar en cuenta que la imagen colectiva de esos indígenas como grupos nómadas y «salvajes» era en la época -y lo ha sido hasta hace no mucho más de diez años- no ya hegemónica, sino monolítica.

En consonancia con estas ideas, todos los que opinaron acerca de «qué hacer con el indio» en un debate que se prolongó varios años -y que puede seguirse en libros de la época, en documentos oficiales y sobre todo en las columnas de los periódicos ${ }^{35}$ - compartieron tres premisas fundamentales que nadie puso en discu-

\footnotetext{
34 Citado en Silvia FRIDMAN, «La situación del indígena a través del periodismo», en Congreso Nacional de Historia sobre la Conquista del Desierto, Buenos Aires, Academia Nacional de la Historia, 1980, TomoIV, pp.377-387; cita en p.378.

35 Estos debates pueden seguirse en los periódicos La Nación, La Prensa, El Nacional y La Tribuna, todos ellos de Buenos Aires. Véase también, entre otras obras de la época, Francisco P. MoREno, Viaje a la Patagonia Austral, Buenos Aires, Ediciones El Elefante Blanco, 1997 (primera edición: 1879); Alvaro BARRos, Indios, fronteras y seguridad interior, Buenos Aires, Solar/Hachette, 1975 (texto editado por primera vez en 1877 bajo el título La Memoria Especial del
} 
sión. Primero, la necesidad de hacer la guerra al indio para eliminar definitivamente las fronteras interiores, afirmando la soberanía argentina y abriendo ese espacio a la «civilización». Segundo, la aspiración a construir una nación homogénea y moderna. Tercero, el convencimiento de que una condición sine qua non para cumplir este objetivo era la desaparición de los elementos retardatarios, es decir, de aquellos grupos humanos que no compartían las supuestas premisas de la «vida civilizada». Se trataba pues de la puesta en marcha de claras dinámicas de exclusión. El interrogante que esto plantea es: cuáles eran los mecanismos y los límites que daban contenido específico a esa exclusión.

Significativamente, no parece haber gozado de favor la idea de acelerar la extinción física de esos «elementos retardatarios». Por el contrario, cada vez que trascendió al público algún procedimiento militar que se consideró «cruel e innecesario», éste recibió durísimas críticas en los medios de opinión ${ }^{36}$. De hecho, existía una suerte de fatalismo según el cual «...no siendo posible exterminarlos, desde luego, por las armas, hay que resignarse a que el tiempo y el trabajo perseverante, inteligente, valeroso, del pueblo y del gobierno, resuelvan esta ardua cuestión que existe y existirá hoy, lo mismo que mañana y dentro de muchos años» ${ }^{37}$.

No tuvo tampoco gran aceptación el modelo norteamericano de delimitación de «reservas», salvo en el caso de algunas voces aisladas como la del científico y explorador de la Patagonia, Ramón Lista, o unos pocos legisladores cuyos alegatos en las cámaras quedaban siempre en minoría ${ }^{38}$. Una cita tomada de un periódico de 1878 resume de forma elocuente la perspectiva más extrema desde la cual se abordó la cuestión del indio:

«Estamos empeñados en una contienda de razas en que el indígena lleva sobre sí el tremendo anatema de su desaparición, escrito en nombre de la civilización. Destruyamos pues moralmente esa raza, aniquilemos sus resortes y organización política, desaparezca su orden de tribus y si es necesario divídase la familia.

Esta raza quebrada y dispersa, acabará por abrazar la causa de la civilización.

Las colonias centrales, la marina, las provincias del litoral sirven de teatro aparente para realizar este propósito» ${ }^{39}$.

\footnotetext{
Ministro de la Guerra, Buenos Aires). Estanislao ZeBAllos, La conquista de las 15.000 leguas, Buenos Aires, 1958 (2a. edición 1878). Para estos temas, es útil el conjunto de trabajos presentados al Congreso Nacional de Historia sobre la Conquista del Desierto [34].

36 Por ejemplo, el fusilamiento de 60 indios ranqueles que se produjo en la provincia de Córdoba en 1878 fue comentado con indignación por los periódicos a lo largo de varios días. Véase especialmente La Nación y La Tribuna, Buenos Aires, noviembre de 1878.

37 La Nación, Buenos Aires, 1 de enero de 1876.

38 Véase por ejemplo la sesión del 19 de agosto de 1885, en la que sólo un legislador abogó por este modelo. Diario de Sesiones de la Cámara de Diputados, Buenos Aires, 1886.

${ }^{39}$ La Prensa, Buenos Aires, 1 de marzo de 1878.
}

R. I., 1999, n. ${ }^{\circ} 217$ 
Es decir: la opinión mayoritaria se inclinaba por integrar a los indígenas en la propia sociedad, pero sólo a condición de que se incorporasen a la «vida civilizada», asumiendo forzosamente sus usos, formas, reglas y moral. Tal objetivo implicaba anular la organización tribal de los aborígenes, borrar sus costumbres e incluso sus lenguas, escolarizar a sus hijos y convertirles, en general, en «trabajadores productivos», como precio ineludible para concederles derechos de ciudadanía. El consenso mayoritario sobre este tema se rompía en lo referente a los medios -más o menos graduales, más o menos traumáticos- que había que aplicar para lograr esa asimilación. Algunos -como el propio general Roca- abogaban por su dispersión en las distintas regiones de la república. Otros pedían que se les «quitase el caballo» y se les obligara «a punta de remington» a abandonar el nomadismo ${ }^{40}$, agregando a ello la acción del misionero según el axioma de que «cristianizar es civilizar». Finalmente estaban los que preferían la concesión de tierras y la interacción en ellas del indio y el colono europeo.

Entre los partidarios de esta última solución se encontraba uno de los principales ideólogos de la Conquista del Desierto, el militar y político Alvaro Barros. Este personaje consideraba imprescindible la guerra ofensiva contra el indio, pero condenaba lo que entendía como «el sistema bárbaro de exterminar a la raza indígena». De hecho, en tanto gobernador del territorio meridional del Río Negro (uno de los espacios «conquistados» en la campaña), Barros fomentó el establecimiento de colonias agrícola-ganaderas de población mixta, es decir, integradas por inmigrantes de origen europeo y por indígenas. Su objetivo último queda elocuentemente expresado en una frase particularmente significativa:

«...pensamos que el indio debe tener entrada y asiento en el parlamento argentino; pero no por cierto el indio tal cual se encuentra en la pampa, un tanto ajeno a los usos parlamentarios; sino el indio del porvenir, el descendiente de la hija de Namuncurá ${ }^{41}$, perla del desierto transportada al centro de la civilización, y unida por el vínculo conyugal al inmigrante irlandés cuyos antepasados, ahora tres siglos, no más, no eran ni más ni menos indómitos ni menos feroces que Namuncurá» 42 .

Es decir, Barros, y con él un sector mayoritario de la opinión pública, no ponían en duda el carácter «retardatario» del indio de la pampa y la Patagonia. Tampoco mantenían una postura de tolerancia hacia sus prácticas culturales. Pero defendían su derecho a la vida y a perpetuarse físicamente en una progenie, a cambio, eso sí, de su integración cultural en la sociedad mayoritaria. Esa integración cultural era condición sine qua non para ser incluido en la nación. Desde

40 Zeballos [35].

${ }^{41}$ Hijo de Calfucurá, su heredero y último dirigente del gran cacicato de la región pampeana.

42 BARros [35] pp. 357-8. 
esta perspectiva las fronteras de la exclusión no afectaban al indio biológico, sino a su forma tradicional de vida, y el derecho a la perpetuación física del primero se defendía sobre el principio clásico e ilustrado de que los estadios culturales son susceptibles de modificación. Ello implicaba, a su vez, el rechazo implícito de las perspectivas más extremas (es decir, las que consideraban que los indígenas estaban lastrados por una inferioridad biológica que les impediría incorporarse a la civilización).

En realidad, esta preferencia mayoritaria por una perspectiva asimilacionista tenía raíces en la propia tradición de tratamiento con el indígena y, en particular, en las políticas aplicadas durante los últimos tramos del gobierno colonial. Como ha puesto de manifiesto David Weber ${ }^{43}$, el pensamiento ilustrado español concibió una forma de tratamiento de los indígenas de frontera basada en lograr que éstos se convirtieran en «súbditos útiles de la Corona», a partir de un procedimiento que combinaba la presión militar con el comercio. Se esperaba que los «indios bárbaros» «serían sensibles a los beneficios de la nueva situación y voluntariamente y siguiendo su propio interés se convertirían en productores y consumidores», asumiéndose como «españoles» ${ }^{44}$. Esta tradición de pensamiento contribuye a explicar la fuerza con que se impuso mayoritariamente una idea de inclusión asimilacionista en el período republicano y, más concretamente, a partir del sojuzgamiento de los indígenas hasta entonces independientes. En este último período, en el contexto de la construcción nacional argentina la pulsión asimilacionista se vinculó estrechamente al problema de la conversión del «indio bárbaro» en ciudadano del Estado-nación.

\section{CIUDADANIZACIÓN Y POLÍTICA' DE TIERRAS}

En efecto, lo que subyacía a las discusiones sobre «qué hacer con el indio» y al pensamiento mayoritario que en ellas se expresaba era el tema de la ciudadanización del indígena. En un momento en que la organización nacional estaba llegando a su cénit y problemáticas tales como la ciudadanía, la representación o la soberanía constituían elementos primordiales del debate general, la situación estatutaria y jurídica del indio en el marco del estado-nación -es decir, de un porcentaje de la población nacido y criado en el territorio nacional - no era una cuestión que pudiera despacharse con frivolidad.

El año en que comienza la última gran ofensiva sobre las tribus indígenas -1878 - el Poder Ejecutivo diseñó una filosofía básica que habría de convertirse en el modelo sobre el cual se recortarían las medidas destinadas a modificar

\footnotetext{
43 WEBER [8].

${ }^{44}$ Idem, p. 154. Sobre la aplicación de estas propuestas en el Río de la Plata véase el trabajo de Guillermo Wilde en este mismo volumen.
}

R. I., 1999, n. $^{\circ} 217$ 
íntimamente la situación vital del indígena sometido por las armas ${ }^{45}$. Esta filosofía se fundaba en que los indígenas eran seres «desgraciados, cuyos crímenes tienen tal vez por causa única, la miseria, la ignorancia y el atraso». Por ello, el fundamento de toda acción política debía estar orientado a que el indígena no pudiese mantener «su espíritu de cuerpo, sus propensiones y sus hábitos salvajes»:

«Ni la conveniencia del país, ni el interés mismo de las tribus sometidas, ni los deberes que impone la buena política de humanidad, son compatibles con este estado de cosas. Y después de la meditación que el asunto requiere, el Sr. Presidente piensa que podría cambiarse favorablemente esta situación, dando a los grupos de indios una colocación que los alejase del desierto, que los separase de las connivencias, vecindades y sugestiones que los llevan muchas veces a ejercitar sus depredaciones. Que los pusiera, por último, en más inmediato y eficaz contacto con las poblaciones civilizadas, desde que ese contacto se buscase con la previsión suficiente a evitar todo daño» ${ }^{46}$.

Esta filosofía fundamental alcanzó su cenit cuando en 1885 -el mismo año en que culminó la Conquista del Desierto en su fase pampeana y patagónica- el Poder Ejecutivo presentó ante el Congreso un proyecto de ley para el asentamiento de indígenas en colonias agrícola-pastoriles ${ }^{47}$. La cámara de diputados modificó el proyecto original para eliminar del texto todo rasgo de diferenciación. Desapareció la palabra tribu para ser reemplazada por familias, puesto que «ninguna tribu puede existir ya en el país». Se eliminó también la figura de «comisarías especiales» que habían de tener por jefes a los propios caciques, sobre la fundamentación de que no debía haber autoridades diferenciadas de las establecidas por las propias leyes que regían a la República. Se suprimieron las referencias al envío de los niños indígenas a la escuela, o a la obligación de cumplir con el servicio militar, ya que todo ello estaba previsto en las leyes generales. La comisión encargada de revisar el proyecto del Poder Ejecutivo había partido -según se afirmó en la cámara- «del verdadero punto de vista, considerando a los indios no como tales, como individuos de distinta raza y de otra naturaleza, sino como ciudadanos argentinos» ${ }^{48}$.

Esta perspectiva, mucho más que cualquier consideración de orden moral, era lo que subyacía al rechazo mayoritario hacia el modelo norteamericano de reservas, defendido en solitario por un legislador a partir de tres premisas fundamentales que presentó asociadas entre sí: 1) que era antinatural mezclar al indio -«esa

45 Nota de la Presidencia de la Nación al Ministerio de Guerra y Marina fechada el 6 de marzo de 1878, publicada en La Nación, Buenos Aires, 8 de marzo de 1878.

46 Ibidem.

47 Sesiones del 19 y 26 de agosto de 1885, Diario de Sesiones de la Cámara de Diputados, Buenos Aires, 1886, pp.459-467 y 531-538.

48 Idem, p. 461. 
especie de animal feroz entregado a sus vicios y a las pasiones sin freno que le dominan»- con poblaciones civilizadas e indefensas; 2) que no se debía destruir su organización y sus leyes sin pasar por un período prolongado de aprendizaje por medio de la acción del sacerdote y la escuela («los dos únicos elementos civilizados a los cuales se ha subordinado históricamente el indio»); y 3) que el intento de destrucción acelerada de su organización secular podía no sólo causarles un grave mal sino entrañar, por reacción, un retorno a las épocas del maloqueo. Por todo ello propuso como preferible el modelo norteamericano de negar a los indios la condición de ciudadanos, manteniéndolos en reservas donde permanecían sujetos a sus propias normas en lo que se refería a sus controversias entre sí, y sólo se les aplicaban las leyes generales en sus tratos con la sociedad mayoritaria ${ }^{49}$.

Esta propuesta cayó en terreno baldío, no porque los honorables legisladores defendieran una visión más benévola del indígena, sino porque la filosofía asimilacionista del decreto propuesto estaba en perfecta consonancia con la perspectiva absolutamente territorial inherente al modelo de construcción nacional aplicado en la Argentina. Según ésta, «el indio nacido en la República Argentina, por la constitución, por la ley de ciudadanía, es ciudadano por el hecho de haber nacido en nuestro territorio» ${ }^{50}$. El ius solis se ponía así por delante de toda consideración acerca del estado de evolución de los indígenas, e impedía considerarles «una clase aparte», ya que «indígenas son todos los ciudadanos de la República, con excepción de los naturalizados. Indígenas somos todos los miembros del congreso, lo son los del Poder Ejecutivo (...) Y entonces legislamos para ciudadanos, porque la ley de ciudadanía dice: 11 'Son argentinos todos los que han nacido o nazcan en el territorio de la República' ${ }^{51}$. Una vez puesta en salvo esta premisa, ya podía entrar en juego la ley de la naturaleza y destinarse el proyecto en discusión «a dirigir la evolución por la cual pasan todas las razas humanas en una de sus fases más difíciles: la transición de la vida nómade a la vida sedentaria» ${ }^{52}$.

De tal forma, la sujeción a un concepto exclusivamente territorial de la nación contribuyó a la puesta en marcha de un modelo estrictamente asimilacionista, que fue llevado a la práctica concienzudamente mediante la aplicación de la mayoría de las recetas propuestas, con grado variable de éxito. Dos temas fueron particularmente importantes. Por un lado la escolarización de los niños fue una preocupación temprana, y en plena compaña del desierto aparecen informes entusiastas sobre la asistencia de pequeños indígenas a las escuelas que se iban abriendo a medida que se asentaban poblaciones en los territorios recientemente

\footnotetext{
49 Idem, p. 462.

50 Idem, p. 532.

51 Idem, p. 460.

52 Idem, p. 458.
}

R. I., 1999, n. 217 
conquistados $^{53}$. Esta preocupación inicial se convirtió en ley en 1885, al decretarse, junto con el asentamiento rural de familias indígenas, que éstas estaban obligadas a mandar a la escuela a sus hijos de ambos sexos, entre la edad de 8 y 12 años $^{54}$. Por otro, fue una preocupación prioritaria la adscripción inmediata de cada indígena a una situación laboral, para convertirle «en un elemento activo de trabajo que contribuya a la riqueza pública y se reforme, asociando su existencia a los centros de poblacion, y educando a su familia en los hábitos que la sociedad civilizada profesa» ${ }^{55}$. Sería un error atribuir esta política de adscripción al trabajo a una voluntad de generar mano de obra barata. En la perspectiva de las élites, las necesidades de mano de obra debían subsanarse prioritariamente mediante la atracción de contingentes inmigratorios europeos, verdadero fundamento de la construcción nacional argentina. La propuesta de convertir al indio en trabajador se relacionaba, en términos generales, con el imperativo de «civilizar al indio bárbaro»; $\mathrm{y}$, en términos particulares, con una necesidad más inmediata. Como afirmaba un diputado en el Congreso de la Nación:

«... el cuidado de los indios causa ingentes gastos a la Nación, por cuya razón es indispensable hacerles trabajar para que puedan costear su subsistencia; y para ello es necesario darles recursos, es decir, la tierra, los elementos de labranza, todo lo que damos al estrangero. No es justo que á los naturales los coloquemos en peores condiciones que á los que vienen del estrangero, pues esto sería llevar la luz á la vecindad y la oscuridad á la casa propia» ${ }^{56}$.

En consonancia con este tipo de planteamientos, la acción política más importante con respecto al tratamiento del indio sometido fue la relacionada con la concesión de tierras. La ley general sobre el establecimiento de los indígenas

53 Véase por ejemplo este telegrama enviado al Presidente de la República, Nicolás Avellaneda, por un sargento mayor desde su campamento militar al sur de la provincia de Buenos Aires: «Tengo el honor de comunicar a Vuestra Excelencia una nueva conquista de la civilización contra la barbarie, que acaba de realizarse en este campamento, un día después de la inauguración del telégrafo de la Blanca. Acabo de inaugurar una escuela de primera enseñanza donde, en este momento y dirigidos por Olivares, telegrafista de esta frontera, empiezan a recibir educación treinta y dos niños. Doce son de la tribu indígena que existe en este campamento, su número aumentará, así que puedan vestirse algunos que no tienen absolutamente cómo hacerlo para concurrir a las clases. Vuestra Excelencia, que como Ministro de Instrucción Pública hizo tanto por difundir la enseñanza en la República y que continúa, como Presidente, prestándole su atención, no dudo que recibirá con agrado esta noticia y que prestará su apoyo». Telegrama fechado el 14 de julio de 1879 y reproducido el 15 de julio por el periódico El Nacional de Buenos Aires. 1885.

${ }^{54}$ Diario de Sesiones de la Cámara de Diputados, Buenos Aires, sesión del 26 de agosto de

${ }^{55}$ La Nación, Buenos Aires, 9 de marzo de 1878. 1885.

56 Diario de sesiones de la Cámara de Diputados, Buenos Aires, sesión del 26 de agosto de 
sometidos en colonias (llamada por algunos la Ley Argentina del Hogar, parafraseando al Homstead Act de los Estados Unidos) fue seguida por otras disposiciones complementarias destinadas al asentamiento de colonias agrícola-pastoriles de base mixta o estrictamente indígenas. Aunque el espíritu de la ley era favorable a la creación de grupos poblacionales mixtos, con el fin de «mezclar estos indios con la población civilizada, de tal manera que en el menor tiempo posible se encuentren á la altura de civilización de los demás habitantes de la República» ${ }^{57}$, en la práctica resultó más sencillo y frecuente el asentamiento de colectivos exclusivamente indígenas, aunque en las inmediaciones de poblaciones «blancas» ${ }^{58}$. Esto último se hacía mediante la entrega de tierras a grupos de dimensiones diversas que estaban al mando de uno o más caciques. El caso más famoso es el de la concesión en propiedad de tierras de extensión variable a los más importantes caciques, como el mapuche Namuncurá o el jefe manzanero Sayhueque. En el primer caso, el congreso destinó 20.000 hectáreas de tierra a Namuncurá y su gente en el territorio del Neuquén ${ }^{59}$. En el segundo, se concedieron 30.000 hectáreas de tierra a Sayhueque y las familias de su tribu en el territorio del Chubut ${ }^{60}$. Pero la documentación guarda un número importante de casos de caciques menos conocidos, como Tripailaf, Mariano Pichihuincá61, Juan Centeno, Kankeli, Juan Andrés Antemil, Luis Baigorrita, Rafael Ancalao, Cheuquel, Paineque o Piliarín Curical ${ }^{62}$-por citar sólo algunos- que recibieron tierras en su mayoría en usufructo (la entrega en propiedad era menos frecuente) para establecerse en ellas junto con los restos de sus tribus.

La ley establecía la entrega de semillas, herramientas y animales de cría y de labor para favorecer el asentamiento inicial. Lo mismo se asignaba a los inmigrantes, con la diferencia de que estos últimos asumían una deuda con el Estado que debían saldar en un número de años, mientras que los indígenas recibían dichos elementos sin cargo alguno. Se esperaba con estas medidas que no hubiese «un solo ciudadano argentino en nuestro territorio que no entre por la vía del progreso y de la civilización por que marcha el país» ${ }^{63}$. Pero este fin genérico se apoyaba en el objetivo mucho más concreto de que pudiesen costear su subsis-

\footnotetext{
57 Idem, p.461.

58 En las discusiones que se llevaron a cabo en la cámara de diputados sobre el proyecto de ley para asentamientos indígenas, uno de los temas debatidos (y no resueltos) fue si los grupos debían establecerse en las inmediaciones de las poblaciones blancas o directamente en los ejidos de las colonias.

${ }^{59}$ Ley No. 3092 de 16 de abril de 1895.

${ }^{60}$ Ley No. 3814 de 26 de septiembre de 1899.

61 Concesión de tierras en La Pampa a los caciques Mariano Pichihuincá y Manuel Tripailaf, Archivo General de la Nación, Sección de Tierras y Colonias, Caja No. 1 expediente 1629.

62 Archivo General de la Nación, Sección Tierras y Colonias, libro 9 foja 32, libro 10 foja 66, libro 13 foja 256 y ss., libro 15 fojas $574-575$, libro 35 fojas 215 y 140, libro 36 foja 18 y libro 39 foja 68.
}

${ }^{63}$ Diario de Sesiones de la Cámara de Diputados, Buenos Aires, 1886, p. 462. 
tencia, no sólo por ser éste un acto de justicia, sino porque -como se ha dicho antes- el sostenimiento de los indios sometidos mediante la asignación de vituallas era una carga no desdeñable para el erario público. Hacia 1885 , es decir, al finalizar la campaña en los territorios meridionales, se hallaban en esa situación alrededor de 8.000 familias aborígenes cuyo mantenimiento se calculaba en 30.000 pesos mensuales ${ }^{64}$.

De esta manera se crearon varias colonias agrícola-pastoriles, como la denominada General Emilio Mitre, en La Pampa central, habitada en su mayoría por indios ranqueles. O las colonias pastoriles Catriel, Valcheta, Cushamen y Los Puelches, pobladas con indígenas que previamente habitaban los territorios de $\mathrm{La}$ Pampa, Río Negro, Chubut y Santa Cruz ${ }^{65}$. Algunas de estas colonias tenían una extensión considerable: las de Valcheta y Catriel, por ejemplo, ocupaban cada una 125.000 hectáreas de superficie ${ }^{66}$; a la colonia General Emilio Mitre se le concedieron 80.000 hectáreas ${ }^{67}$. Es interesante destacar que aunque la aspiración oficial era a la interacción de grupos indígenas y «colonos de raza europea» en los terrenos de las colonias, y que este objetivo quedaba expreso en los decretos de establecimiento de las mismas, estos últimos incluían también, por lo general, un artículo que daba prioridad en la adjudicación de lotes a los indígenas del lugar ${ }^{68}$.

Algunas colonias, como la General Conesa y la General Eustaquio Frías en el territorio del Río Negro ${ }^{69}$, comenzaron siendo colonias mixtas -pobladas por restos de tribus indígenas y elementos criollos y extranjeros- pero por su propia depauperación terminaron abandonadas por el elemento blanco y habitadas casi exclusivamente por indígenas. Una de las razones de su empobrecimiento fue el hecho de que el tipo de tierras sobre las cuales estaban asentadas requería de regadíos y obras de infraestructura que nunca fueron realizados ${ }^{70}$. La colonia General Conesa, una de las más tempranas, fue fundada por decreto de 14 de febrero de 1879 con una extensión de 10.000 hectáreas subdivididas en 100 lotes. El terreno era sumamente quebrado, las chacras de las vegas eran anegadizas en épocas de creciente y las de las lomas sólo cultivables con riego, pero era difícil practicar canales a causa de su gran elevación. Ello implicó el estancamiento de la colonia y veinte años después de su creación sólo la habitaban unas pocas fa-

\footnotetext{
${ }^{64}$ Diario de Sesiones de la Cámara de Diputados, 16 de octubre de 1885.

65 Cfr. Memoria presentada al Honorable Congreso de la Nación por el Ministerio de Agricultura, por el Ing. Octavio S. Pico, Buenos Aires, 1899-1900, pp.LV.

66 Archivo General de la Nación, Sección Tierras y Colonias, libro 21 fojas 55 y ss.

${ }^{67}$ Memoria del Ministerio de Agricultura, enero-octubre 1900, p.LV.

68 Véase por ejemplo el decreto de trazado y amojonamiento de la colonia Valcheta, Archivo General de la Nación, Sección Tierras y Colonias, libro 21 fojas 55 y ss., y el de creación de la colonia Los Puelches, íbidem.

${ }^{69}$ No casualmente, Río Negro era la gobernación encabezada por Alvaro Barros.

$70 \mathrm{Idem}$, pp.12 y ss. y Memoria presentada al Honorable Congreso de la Nación por el Ministro de Agricultura, Ing. Alfredo Demarchi, en el año de 1918. Edición del Ministerio de Agricultura de la Nación hecha en Buenos Aires, 1920.
} 
milias indígenas ${ }^{71}$. Caso contrario fue el de la colonia General Roca, cuya población blanca se expandió gracias al desarrollo que produjo la construcción de un canal de riego en la que tomaron parte cuarenta peones indígenas de la tribu de Namuncurá72. En 1889 se calculaba que el $10 \%$ de la población de esta colonia estaba integrada por «indios civilizados» ${ }^{73}$.

En los centros urbanos alejados de los territorios recientemente conquistados, como la propia Buenos Aires, el asentamiento de los indígenas en las nuevas tierras como un primer paso para convertirlos en «ciudadanos de provecho» fue recibido con entusiasmo y como una muestra más de que el avance de la civilización era tan necesario como inexorable. Las solicitudes de tierra por parte de los caciques fueron acogidas en general con un beneplácito que podía asumir tanto expresiones de entusiasmo civilizatorio como de ironía urbana frente a formas culturales consideradas inferiores. Muestra de lo primero es la nota manuscrita que en 1894 presentó ante el Congreso el Presidente de la República, Luis Sáenz Peña, apoyando el pedido de tierras del cacique Namuncurá, por considerar «un hecho bien significativo el que uno de los antiguos señores de la pampa venga a reclamar, empleando los recursos y procedimientos creados por las leyes, un pedazo de tierra para hacerla suya con su trabajo e incorporarse a la civilización». Ello era prueba, según el Presidente, de «que también esa raza indómita, altiva en su salvajismo, se presenta dominada, subyugada por la civilización, a reclamar su puesto de labor, trayendo su cooperación en bien del engrandecimiento y prosperidad de nuestro país» ${ }^{74}$.

La sociedad urbana aceptaba la entrega de tierras a los indígenas, pero no dejaba de señalar -incluso apelando al sentido del humor- la enorme distancia evolutiva que separaba a esas formas culturales inferiores del propio y glorioso estadio de civilización. Con ironía relataba en 1899 una publicación periódica muy leída por la mejor sociedad de Buenos Aires:

«Está de moda la venida de pequeños soberanos indígenas a la metrópoli. Tenemos entre nosotros á Nancucha Nahuelquir, cacique araucano mapuche, y a Bibiana García, caciquesa de los restos de la otrora grande y poderosa tribu del desgraciado Catriel. Uno y otra vienen al foco de la civilización argentina con un fin pacífico de plausible sumisión. Vienen a pedir campos para fundar de manera estable sus hogares, antes vagabundos, en sitio fijo y sobre tierra propia. La casa (de Bibiana) es característica: tiene algún vago cariz de parade-

\footnotetext{
${ }^{71}$ Memoria presentada al Honorable Congreso de la Nación por el Ministerio de Agricultura, por el Ing. Octavio S. Pico, Buenos Aires, 1899-1900, pp. 12 y ss.

72 Diario de Sesiones de la Cámara de Diputados, Buenos Aires, 18 de junio de 1888.

73 Memoria del Ministerio del Interior correspondiente al año 1888, presentada al Honorable Congreso de la Nación en 1889. Imprenta Sudamérica, Buenos Aires, 1889.

74 Fechada en 10 de agosto de 1894 (manuscrito). Archivo General de la Nación, Sección de Tierras y Colonias, libro 1 foja 143.
}

\section{R. I., 1999 , n. $^{\circ} 217$}


ro. En primer lugar el barrio, casi agreste, allá por donde hacia el sudoeste, parece que empieza Buenos Aires a acabarse, tragado por los zanjones y engullido por los barriales. Luego un muro a la calle, un portoncito tembleque, y adentro el campamento, lo más primitivo posible» ${ }^{75}$.

En los nuevos territorios, la concesión de tierras a los caciques no fue siempre recibida con tanto beneplácito. En la documentación suelen aparecer con bastante frecuencia notificaciones de la Dirección de Tierras y Colonias a los gobernadores de los territorios nacionales, ordenando a estos últimos amparar con las fuerzas del orden a su cargo el establecimiento de los indígenas en las colonias y terrenos concedidos, lo que sugiere que la resistencia de las poblaciones blancas a dichos asentamientos no era inusual ${ }^{76}$.

Precisamente el rechazo al establecimiento de grupos indígenas en los territorios recientemente conquistados, unido al planteamiento de «civilización a marchas forzadas» que constituía la respuesta mayoritaria al problema de «qué hacer con el indio», fue lo que inspiró el sistema de dispersarlos por distintos puntos de la República. Desde el comienzo de la campaña ofensiva se discutió la conveniencia de enviar a los indios sometidos a la provincia de Buenos Aires, con la idea de que «encuentren en el trabajo activo y honrado la base de su existencia y su futura prosperidad, diseminándolos por familias para que cambien hábitos y costumbres, y no sean una amenaza a la población si permanecen en tribus, mal valijados y atendidos ${ }^{77}$. La aplicación de esta medida dio lugar no sólo a la dispersión por grupos familiares, sino incluso a la separación de padres e hijos, siendo los niños a veces entregados para su crianza a familias blancas, con la intención de aislarles de toda influencia «bárbara». Este tipo de medidas dio lugar a indignadas críticas por parte de individuos e instituciones, en particular la Iglesia Católica, que se opuso con fervor a lo que en su opinión «quebrantaba las leyes de la naturaleza que ejercen un influjo hasta en los seres irracionales». Asimismo, en opinión de las jerarquías católicas, «si se les lanza [a los indígenas] sin ningún género de preparación a las ciudades y a los campos, adquirirán los vicios consiguientes a la civilización que encontrarán en su ignorancia un campo fecundo» ${ }^{78}$.

A pesar de las críticas, el sistema de dispersión continuó a lo largo de toda la campaña de la Patagonia. En sus últimos tramos, un importante dirigente militar concibió una variante de ese tipo de medidas que tuvo como resultado uno de los episodios más tristes de esta por sí triste historia. El general Lorenzo Vintter, Comandante en Jefe de la Segunda División del Ejército y a partir de 1886 Go-

75 Caras y Caretas, Buenos Aires, año I, junio 1899, No. 38.

76 Véase, por ejemplo, Archivo General de la Nación, Sección Tierras y Colonias, libro 35 foja 215 y libro 10 foja 311 .

77 La Nación, Buenos Aires, 16 de junio de 1878.

78 La América del Sur, Buenos Aires, 29 de noviembre de 1878 (este periódico expresaba las posiciones de la jerarquía católica).

R. I., 1999, n. ${ }^{\circ} 217$ 
bernador del territorio nacional del Río Negro, fue un enemigo acérrimo de la permanencia de indígenas en los territorios conquistados. El sistema de mantener mediante racionamiento a las tribus sometidas era considerado por este militar «injustificable por pernicioso», ya que «además de postergar con este medio su entrada en la vida común de los pueblos civilizados, se creen aún poderosos, terribles y capaces de convulcionar (sic) al país». Una segunda forma de mantenimiento de los indígenas, basada en la libertad de comerciar con los establecimientos blancos, era también rechazada por Vintter pues por ese medio «se proveen de cuanto les es necesario para prolongar su vida errante y salvaje», por lo que solicitó oficialmente su prohibición ${ }^{79}$. Pero tampoco el asentamiento de indígenas en colonias era aprobado por este militar. De hecho, llegó a pedir la disolución de la colonia General Conesa, negando su utilidad para la conversión de los indígenas en población sedentaria («sus pobladores no han cambiado en nada su condicion feroz, indolente y holgazana» $\mathrm{y}$ «ninguna idea tienen del bienestar de los pueblos sedentarios» ${ }^{80}$ ), y reclamó que «los pocos hombres útiles con que cuenta» fueran distribuidos en diversos establecimientos o se les permitiera internarse en la provincia en busca de trabajo como peones jornaleros.

A medida que iba ocupando los nuevos territorios Vintter aplicaba la política de dispersión, hasta el punto de embarcar tribus completas con destino a Buenos Aires ${ }^{81}$. Esto fue muy mal recibido en la capital, donde la mayoría de los periódicos pusieron el grito en el cielo ante lo que consideraban una forma inhumana y poco práctica de tratamiento de la cuestión indígena. La fulminante respuesta de Vintter fue informar tanto al Ministro de la Guerra como al propio Presidente de la República que «lejos de atenerse a esa falsa propaganda» seguiría remitiendo a la capital a «cuanto indio caiga en mi poder» 82 .

Unos años más tarde el iracundo general encontró una nueva manera de tratar el problema: sugirió que varias familias aborígenes del Río Negro fueran distribuidas «en aquellos puntos a donde fuesen reclamadas por el trabajo y un nuevo género de vida. En tal sentido, para estos indígenas del Sud sería apropiada la traslación a las fértiles comarcas del Norte de la República, [el territorio nacional

\footnotetext{
${ }^{79}$ Lorenzo Vintter al Ministro de Guerra y Marina, fechada en Patagones a 1 de septiembre de 1880, Archivo General de la Nación, Sala VII, leg. 16-6-20.

80 Ibidem.

${ }^{81}$ Las listas individualizadas se guardan en el Archivo General de la Nación, Sala VII, leg. 10.6.20. Son comunes documentos como la siguiente carta dirigida al General Vintter por un capitán de barco y fechada en Río Negro el 30.7.1885: «Tengo el honor de poner en conocimiento de VS que hoy día de la fecha he recibido a bordo de este buque 131 indios de lanza y 3 mujeres para conducir a la capital, como igualmente con fecha 23 catorce indios y 3 mujeres entregados por el Sr. comandante Palacios, y haciendo un total de 145 indios y 6 mujeres. Habiendo cumplido la orden recibida de VS, sólo espero orden para zarpar mañana». AGN, Sala VII, leg. 10.6.19.

${ }^{82}$ De Lorenzo Vintter al Presidente de la República, Gral. Julio A. Roca, fechada en Chubut a 10 de agosto de 1883. De Lorenzo Vintter al Ministro de la Guerra, fechada en Chubut a 10 de agosto de 1883. Archivo General de la Nación, Sala VII, leg. 10.6.20.
}

R. I., 1999, n. $^{\circ} 217$ 
de] Misiones por ejemplo, donde hallarían pronto y fácil empleo, adquiriendo hábitos de sujeción y trabajo» ${ }^{83}$. Esta sugerencia fue muy bien recibida por el Presidente Roca y no se tardó en ponerla en práctica. Grupos enteros de indígenas acostumbrados a las nieves y los fríos vientos del sur fueron transportados a los climas tropicales del norte y puestos a trabajar en los ingenios azucareros en un régimen de semiesclavitud. Pocos sobrevivieron a la experiencia.

Cuando se hizo cargo del último escenario de la Conquista del Desierto -la región norteña del $\mathrm{Chaco}^{84}$ - el general Vintter modificó sus propuestas. Preocupado como había estado por «vaciar» de indígenas los territorios patagónicos, era coherente que no propusiera el envío de indios chaqueños a las regiones meridionales. El esforzado militar, nombrado Gobernador del territorio nacional de Formosa, recurrió entonces a un sistema tradicional de la conquista hispana: el establecimiento de misiones. No obstante, hijo como era del pensamiento positivista de la época, Vintter consideraba que los misioneros no debían preocuparse de la catequización de los indígenas sino en segundo término. Su primer cometido debía ser «educar y formar el corazón del indio, enseñándole los deberes y preocupaciones del ciudadano. Preparándolo así según el espíritu de nuestras leyes y de nuestros positivos intereses, para que luego puedan aprender los deberes y preocupaciones cristianas». En otras palabras, la misión de los sacerdotes era «mantener al indio constantemente ocupado en tareas de labor y trabajo, directamente corporales, reservando para más tarde las tareas y afanes espirituales a que es preciso e inevitable predisponer razas tan estúpidas y materialistas como aquellas» ${ }^{85}$.

En realidad, el establecimiento de misiones en los territorios conquistados ya estaba previsto en la ley 817 de 1876, de inmigración y colonización, cuyo artículo 100 establecía que el Poder Ejecutivo debía procurar «el establecimiento en las secciones de las tribus indígenas, creando misiones para traerlas gradualmente a la vida civilizada, auxiliándolas en la forma que crea más conveniente y estableciéndolas por familias en lotes de cien hectáreas» ${ }^{86}$. En la práctica, el recurso al sistema de misiones para el tratamiento de la cuestión indígena fue muy minoritario en la Pampa y la Patagonia -a cargo sobre todo de misioneros salesianos ${ }^{87}$,

83 De Lorenzo Vintter al Ministro de Guerra y Marina, fechada en Buenos Aires a 18 de abril de 1888, Archivo General de la Nación, Sala VII, leg. 10.6.20.

${ }^{84}$ En 1884 el Poder Ejecutivo envió al Congreso un proyecto de ley por el cual se le autorizaba a repetir en el Chaco la experiencia militar llevada a cabo en los territorios meridionales.

85 Memoria correspondiente a la División del Litoral. Firmada por Lorenzo Vintter y fechada el 28 de abril de 1900. Archivo General de la Nación, Sala VII, leg. 10.6.21.

86 Citado en Abelardo LEVAGGI, «Muerte y resurrección del derecho indiano sobre el aborigen en la Argentina del siglo XIX», Jahrbuch für Geschichte von Staat, Wirtschaft und Gesellschaft Lateinamerikas, No. 29, 1992, pp.179-194.

87 Sobre la acciones misionales en los territorios meridionales, véase Raúl A. ENTRAIGAS, Los salesianos en la Argentina, Buenos Aires, 1969; Cayetano BRUNo S.D.B., «Técnica misionera en la conquista espiritual de la Patagonia», en Congreso nacional de Historia sobre la Conquista del 
mientras que por el contrario en la ocupación del Chaco, episodio final de la conquista del Desierto, tales instituciones se convirtieron en uno de los pilares de las políticas aplicadas a las poblaciones aborígenes. El asentamiento de indios en poblaciones se hizo en muchos casos a través de la entrega de tierras a frailes franciscanos, mediante un sistema de mensuras, distribución y atención de las mismas prácticamente calcado de los decretos destinados al establecimiento de colonias en los territorios meridionales, con la diferencia no desdeñable de que en las misiones la administración y gobierno de dichas tierras estaba a cargo de los sacerdotes. El Poder Ejecutivo nacional mantenía para sí la prerrogativa de estar representado en la misión por un comisario o delegado especial, que ejercía funciones militares y policiales y dependía administrativamente del gobernador del territorio nacional ${ }^{88}$. Las extensiones concedidas a cada reducción variaban aproximadamente entre 20.000 y 40.000 hectáreas, con zonas delimitadas para ejidos y servicios comunes (escuela, iglesia, plaza y oficinas públicas), y la asignación de 100 hectáreas para cultivo a cada jefe de familia, que al cabo de diez años podía entregársele en propiedad. Es importante señalar, sin embargo, que a pesar de la concesión de tierras y presupuesto para el establecimiento de misiones, este sistema de asentamiento de indígenas tuvo detractores en la época. $\mathrm{Mu}$ chos consideraban que no había medio para «civilizar» a los indígenas del Chaco más efectivo que su colocación como trabajadores en ingenios y obrajes, y que el sistema de misiones estaba desfasado en una época en que era mucho más lo que podían hacer «la escuela, el arado y el intercambio», así como el mestizaje ${ }^{89}$. Por ello se mantuvo también en esta región el sistema de establecer a los indígenas en colonias, siguiendo el ejemplo de la experiencia en las tierras del sur.

En el largo plazo, la política de asentamiento de grupos indígenas en tierras otorgadas en propiedad o en usufructo fue menos exitosa de lo que se esperó en un principio. Hacia finales del siglo XIX había indígenas en la Patagonia que eran ricos propietarios o que poseían buenos establecimientos de campo ${ }^{90}$, pero a la larga una parte no desdeñable de esas tierras fue a parar a manos ajenas. En 1917, el gobierno radical presidido por el Presidente Hipólito Yrigoyen ordenó la realización de una serie de inspecciones para determinar el uso que se había hecho de las tierras públicas en los territorios conquistados al indio y la aplicación práctica de las normativas existentes. Ello permitió constatar la situación general de depauperación en que se hallaba la mayoría de las colonias de base indígena. En el contexto ideológico de la época, una de las razones aducidas fue que se trataba de poblaciones «de entendimiento débil». Los encargados de la inspec-

Desierto [33] 1980, Vol. III, pp.69-83; Enrique Hugo MASES, «La incorporación de los indios reducidos (los intentos salesianos 1880-1881)», ídem, pp.169-178.

${ }^{88}$ Archivo General de la Nación, Sección Tierras y Colonias (entre otros, libro 23, foja 139; libro 34, foja 180).

${ }^{89}$ Diario de Sesiones de la Cámara de Senadores, Buenos Aires, 4 de enero de 1900.

90 Diario de Sesiones de la Cámara de Diputados, Buenos Aires, 18 de junio de 1888. 
ción plantearon asimismo la ausencia de riego artificial como una causa importante de incapacidad de despegue de las colonias. También se tuvo en cuenta la presión permanente que sobre los territorios concedidos a los indios realizaban las poblaciones blancas, en especial las grandes compañías (muchas de ellas extranjeras) que hacían acopio de tierras hasta la formación de inmensos latifundios $^{91}$. Pero a ninguno de los observadores destacados por el gobierno se le ocurrió incluir, como causa fundamental de esa depauperación, la dañina artificialidad del drástico cambio cultural impuesto y la escasa capacidad de maniobra que quedaba a los indígenas, por ignorancia de las formas de la sociedad mayoritaria, para hacer frente al repudio, la coacción y los usos abusivos de esta última.

Por otra parte, lo cierto es que a pesar de la voluntad oficial por asentar a los indígenas en tierras, una parte sustancial de la población de ese origen se incorporó a la sociedad mayoritaria individualmente, en calidad de servicio doméstico, de peones de las estancias ganaderas que se fueron estableciendo al ritmo de la enajenación de los nuevas tierras en los territorios meridionales, y como trabajadores sobreexplotados en los ingenios y obrajes del norte. Asimismo, un número impreciso pero posiblemente bastante amplio de indígenas varones fue enganchado a la policía, el ejército y la marina con bastante éxito de integración. Hacia el final de la ocupación de la Patagonia, alrededor de un $10 \%$ del ejército regular estaba integrado por indígenas tomados prisioneros en la campaña de 1878 y $1879^{92}$, y en fecha tan temprana como 1878 , un periódico de la capital afirmaba que en el servicio de la Marina los indios pampas habían demostrado una excelente capacidad para desenvolverse como marineros ${ }^{93}$. Por otra parte, nada ilustra tan bien la traslación de un universo simbólico a otro como el caso del indígena araucano, miembro de la policía de La Plata, que se opuso a ser sometidos a una sesión de antropometría por parte del antropólogo Herman Ten Kate, del Museo de Ciencias Naturales de esa ciudad, no por miedo a que le capturasen el alma como hubiera aducido veinte años antes, en sus praderas meridionales- sino porque, familiarizado con los métodos lombrosianos de la policía argentina, temía que le estuvieran «tratando como a los vulgares delincuentes» ${ }^{94}$.

En 1879, y a instancias del Ministerio de Justicia, se decidió colocar oficialmente a los indígenas bajo la protección del Defensor de Pobres e Incapaces ${ }^{95}$. Esta medida implicaba, por un lado, reconocer el desamparo en que habían que-

${ }^{91}$ Memoria presentada al Honorable Congreso de la Nación por el Ministro de Agricultura, Ingl. Alfredo Demarchi, en el año de 1918. Edición del Ministerio de Agricultura de la Nación, hecha en Buenos Aires en 1920.

92 Diario de Sesiones de la Cámara de Senadores, 19 de agosto de 1884.

${ }^{93}$ El Nacional, Buenos Aires, 17 de septiembre de 1878.

94 Herman TEN KATE, «Matériaux pour servir à l'anthropologie des Indiens de la République Argentine», Revista del Museo de La Plata, vol. XII, 1905, pp.33-57.

95 Nota de Bonifacio Lastra al Ministro de Guerra y Marina, Buenos Aires, 18 de junio de 1879, reproducida en El Nacional, Buenos Aires, 20 de junio de 1879. 
dado las poblaciones sometidas. Pero por otro, entrañaba también la negativa a integrar a los aborígenes en la categoría de «menores de edad» (defendida entre otros por la Iglesia Católica), considerándolos en cambio como «ciudadanos pobres»; es decir, indigentes y desvalidos, pero ciudadanos al fin. Esta categorización del indígena, que entroncaba con las perspectivas liberales que se habían puesto en marcha con la independencia, fue cuestionada muchas veces por quienes consideraban que para el tratamiento de los indios debía recuperarse el espíritu de las Leyes de Indias, más realistas y comprensivas con su situación diferencial. A este espíritu pertenece el decreto del Presidente Julio A. Roca titulado «Defensa y protección de los indios», según el cual los indígenas de los territorios nacionales se colocarían bajo la protección de los defensores de menores, quienes debían ejercer sobre ellos una acción tutelar y proveerlos por cuenta del Estado de alimentación, vestido y colocación laboral. Por el contrario, fracasó el intento, hacia finales del siglo XIX, de establecer la figura del «Patronato de Indios». Pocos años más tarde, en 1904, el Ministro del Interior Joaquín V. González presentó ante el Congreso un proyecto de ley nacional del trabajo cuyo artículo 273 atribuía a los fiscales el título de «defensores de los indios», con el cometido de ejercer en su favor «las funciones del ministerio público, velando por la justa aplicación de las leyes a todos los actos de la vida civil en que intervengan o que les interesen, amparándolos en sus derechos ante cualquier juez o tribunal, y contra cualquier persona, corporación o empresa que con ellos contrate o utilice sus servicios $»^{96}$. Este intento de colocar a los aborígenes bajo un estatuto particular también fracasó, al no ser aprobada la ley en las cámaras.

\section{EPÍlOGO}

Se fue produciendo así, en el tratamiento legal de la cuestión indígena, una suerte de juego pendular entre el reconocimiento de una situación diferencial de precariedad ante los usos y abusos del sistema, y el imperativo de «ciudadanizar» a cualquier precio a los aborígenes hasta alcanzar su total disolución en la sociedad mayoritaria. La primera tendencia, como hemos visto, tuvo alguna expresión menor en el estatuto legal de los indígenas y, en la cotidianeidad, se tradujo en la permanencia física, aunque empobrecida, del indio como colectivo. La segunda tendencia, en cambio, fue prioritaria en el desarrollo de un imaginario que acabó por eliminar la percepción consciente de la presencia indígena en el conjunto poblacional argentino, fenómeno vinculado en esa misma representación colectiva a un supuesto «exterminio de la raza indígena» como resultado de la acción militar.

\footnotetext{
96 Citado en LevagGi [86] p.189.
} 
Sin embargo, a pesar de las muertes producidas por la ofensiva de las tropas ${ }^{97}$ y por las epidemias y enfermedades debidas a la desestructuración comunitaria y los traslados forzosos de grupos, la gran mayoría de los indígenas sobrevivió y sobre ellos se aplicaron las políticas asimilacionistas antes descritas. La ciudadanización del indio sometido supuso su consiguiente integración como campesinos, peones de estancia o de obrajes, miembros de las fuerzas armadas, efectivos del servicio doméstico y otros destinos, más vinculados a la estratificación de clase que a la diferencia étnica. Ello no implica que no hubiera pervivencias comunitarias en algunos puntos de la República. De hecho, en la actualidad existe aún en la Argentina una población aborigen formada por más de quince grupos étnicos distintos, organizados en sus comunidades de origen, que mantienen sus lenguas originales. Las condiciones deficitarias de los censos impiden un conocimiento exacto de sus efectivos, que varían entre las 150.000 almas de que hablan algunos autores ${ }^{98}$, a los 300.000 o incluso el medio millón que calculan otros $^{99}$. Pero este mantenimiento de algunas estructuras comunitarias -sujetas por lo demás a procesos de desestructuración a lo largo de un siglo, debido a la expoliación de tierras, la depauperación y las migraciones internas ${ }^{100}$ - no es óbice para que la gran mayoría de habitantes de origen indígena haya experimentado una disolución en el conjunto de la nacionalidad argentina, hasta el punto de convertirse en un amplio espectro no diferenciado de la base poblacional.

La ciudadanización del indio no implicó concederles el reconocimiento como argentinos. Este reconocimiento ya lo tenían, a partir de su propia condición de nacidos en el territorio nacional y debido al concepto estrictamente territorial de nación que fue característico de la construcción nacional argentina. Lo que la élite discutió y puso en marcha fue el inicio de un proceso de integración del «indio bárbaro» como ciudadano de la nación, a partir de la concesión de derechos (como la posesión de tierras, la adscripción a situaciones laborales y la es-

97 Según las contabilizaciones más recientes, entre 1821 y 1899 fueron muertos en acciones de guerra 12.335 indígenas de una población calculada inicialmente en 200.000. Cfr. Carlos MARTINEZ SARASOLA [11] p.151 y Anexo II, pp. 555-570.

98 Alejandro O. BALAZOTE y Juan Carlos RADOVICH, La problemática indígena. Estudios antropológicos sobre pueblos indígenas de la Argentina. Centro Editor de América Latina, Buenos Aires, 1992, p. 11.

99 MartineZ Sarasola [11] cap. VIII especialmente pp. 439-445.

100 Un interesante ejemplo de concesión de tierras, ritmos de asimilación y ulterior despojo lo constituye la historia de la comunidad mapuche de Los Toldos, en la provincia de Buenos Aires, a partir de 16.400 hectáreas concedidas en 1866 por el gobierno del general Bartolomé Mitre a la tribu mapuche del cacique Coliqueo, a cambio de defender la frontera de los indios hostiles. Cfr. Gustavo FISCHMAN e Isabel HERNÁNDEZ, La Ley y la Tierra. Historia de un despojo en la tribu mapuche de Los Toldos, Buenos Aires, Centro de Estudios Avanzados de la Universidad de Buenos Aires/Centro Editor de América Latina, 1990. 
colarización) que debían facilitar su conversión simbólica y práctica desde un estadio de barbarie a otro de civilización ${ }^{101}$.

This article analyzes the ways in which «the indigenous problem» was dealt with as a consequence of the military occupation of a huge territory which till then had been inhabited by Indians who were independent from the authority of the central state. It focuses on the complex visions about the Indian and shows that a series of land policies and initiatives destined to the integration of the indigenous population were launched, with the aim to define the place that the submitted Indians should take in the framework of the Argentinian nation-building process. A further argument is about the conditions for the conversion of Indians into citizens in the framework of the Argentinian conceptualization of the nation, which was strictly territorial.

101 Para las matizaciones sobre nacionalidad y ciudadanía me han sido muy útiles las discusiones académicas mantenidas con Marta Irurozqui.

R. I., 1999, n. $^{\circ} 217$ 